\title{
A Case Study of Vanke Equity Dispute Based on Ownership Structure
}

\author{
Yongming Pan, Weipeng Qi \\ Tianjin University of Technology, Tianjin, China
}

\author{
Keywords: Vanke Equity, Ownership Structure.
}

\begin{abstract}
Equity structure is an important part and the foundation of corporate governance, and the adjustment of equity structure is vital to govern the corporate. The dispersed equity structure is always considered to establish the balanced corporate governance mode, but it also can make the corporate caught in the trouble to become the goal of capital mergers and acquisitions. Nowadays the capital market in our country develops fast and steps into the multi-level situation, and there are many capital acquisition events. The real estate industry has been a major part of the national economy, and the relevant enterprises are focused by the capital market. The equity battle of Vanke happened in 2015 and it attracted a lot of attention because of its dispersed equity structure and excellent management structure.
\end{abstract}

\section{Research Background and Significance}

Ownership structure is the foundation and important influencing factors of corporate governance and control. The dispute over ownership of Vanke triggered deep consideration on the ownership structure and corporate governance mechanism in China. This article analyzes the whole story of Vanke in-depth, starting from the ownership structure, and analyzes the enlightenment Vanke shares bring to the design of the equity structure of Chinese enterprises.

Under the situation that most of the equity of listed companies in China is concentrated, Vanke has a decentralized shareholding structure since its establishment. This article will study the formation process of Vanke's unique ownership structure and its impact on corporate governance. In addition, Vanke's management team was praised by the industry. In 2005, Vanke was rated as the best management team and Vanke was the leader in the real estate industry with a relatively decentralized shareholding structure. In contrast, The incident is quite unique and research.

\section{Literature Review}

At present, the research on the ownership structure mostly centers on the concentration of ownership and the nature of the equity. The mainstream divides it into the ownership concentration and the dispersion. With the development of the ownership structure of the company, the research on the equity balance gradually increases. It is generally believed that the structure of the equity balance Too fragmented or too concentrated ownership structure. In recent years, the research on shareholder relations has also gradually increased. It is generally accepted that understanding shareholder relations is conducive to the understanding of the ownership structure and that the research on shareholder relations has gradually become more and more networked from the original linear understanding. In the relationship between ownership structure and corporate governance, whether there is influence between the two and how it affects the academic opinion.

As for the contention of control power, the existing research thinks that its own characteristics lead to the inevitability of competition. The relationship and contradiction between the founder and the investor are the basis of the contention of control power. Because of the key role of the board in corporate governance and the board-centering doctrine Tendencies and domination of power are often manifested in the seizure of seats on the board of directors. As a basic factor, the shareholding structure is more likely to lead to the change of control over the shareholding structure of the controlling shareholder. 


\section{Research content and research methods}

This article uses the method of case analysis to take Vanke equity dispute as the research object. Based on the equity structure, this article explores the essence, causes and effects of the incident, and provides enlightenment to the design of future equity structure.

This article mainly uses the case analysis method, selects the Vanke equity dispute event, unifies the related theories to carry on the analysis from the ownership structure.

Combined with the literature review method, this paper uses the knowledge base, Shenzhen Stock Exchange, Cathay Pacific and other databases for data collection. Based on the research, induction and review of related literatures both at home and abroad, the theoretical basis related to this article is sorted out to serve the article Writing.

\section{Case analysis of Vanke equity dispute}

The shareholding dispute so that the shareholding of Vanke's top five shareholders has increased, the ownership structure from the previous highly dispersed into a relatively concentrated, equity balance has been strengthened.

Vanke's ownership concentration and checks and balances are shown in Figure 4-1. Among the shareholding disputes, the largest shareholder of China Vanke was China Resources prior to September 2015 and since then it has been Baoan. The nature of shareholders has changed from that of a state-owned legal person to others. The proportion of shareholding increased from $14.91 \%$ to $25.40 \%$, and the sum of the shareholdings of the top five shareholders increased from $22.87 \%$ to $65.65 \%$, showing a large increase. The ownership structure obviously tends to be relatively concentrated from highly dispersed.

As for equity balance, with the increase of the shareholding of the largest shareholder and the top five shareholders, the equity balance increased continuously from 0.51 to 1.58 , making Vanke ownership structure unbalanced Type into a balance-type, indicating that the restraint mechanism between shareholders to strengthen. Compared with the non-balance-of-equity structure, the balance-of-equity structure can strengthen the restraint of other shareholders on the major shareholders, thus affecting the corporate governance structure, alleviating the manipulation of major shareholders and encroaching on the interests of other shareholders.

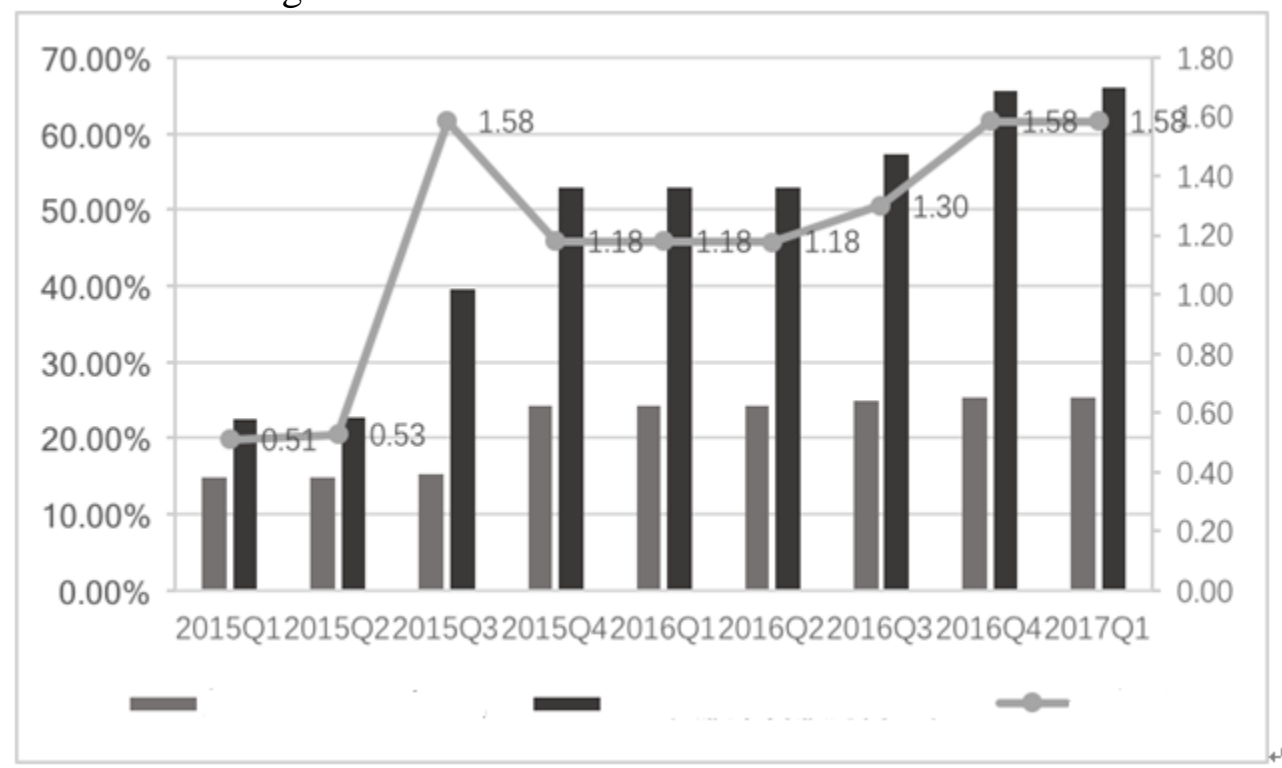

Figure 4-1 Vanke equity balance trend

Multi-investor intervention changed Vanke's original shareholding structure, from the initial highly dispersed ownership structure gradually evolved into a multi-party shareholders can check each other's structure. Although this change is not deliberately, from the highly decentralized 
ownership to equity relative concentration, all parties to strengthen checks and balances, capital markets in the share dispute in the steady ownership of Vanke ownership structure.

\section{Case Revelation}

The articles of association are the contracts that enterprises make under the situation of "Company Law" of our country to regulate the autonomy of the company and promote the good operation of the company. The articles of association should promote the improvement and optimization of the shareholders' general meeting and the board of directors to a certain extent while guaranteeing the interests of the company, shareholders, management and other stakeholders in a balanced manner. In fact, the relationship between the formulation of corporate governance structure and the articles of association of the Company is getting closer and closer. The relevant provisions on transfer of shares and additional issuance are also regulated by the Articles of Association of the Company. Through the Vanke incident, well-designed corporate charter is very important for the business.

Vanke ownership structure is relatively fragmented, relatively easy to become a capital M \& A target, the Articles of Association should become a barrier against the acquisition of China Vanke, but Vanke Articles of Association there are some loopholes. First, there is no set anti-acquisition mechanism, the second is not suitable for major issues. In order to repair Vanke Articles umbrella function, as well as to avoid the dispute again Wanke equity dispute, companies need to amend the Articles of Association to improve and establish a good defense mechanism. In response to malicious mergers and acquisitions, companies should develop effective defensive provisions according to their own circumstances.

Vanke ownership structure is relatively fragmented, relatively easy to become a capital M \& A target, the Articles of Association should become a barrier against the acquisition of China Vanke, but Vanke Articles of Association there are some loopholes. First, there is no set anti-acquisition mechanism, the second is not suitable for major issues. In order to repair Vanke Articles umbrella function, as well as to avoid the dispute again Wanke equity dispute, companies need to amend the Articles of Association to improve and establish a good defense mechanism. In response to malicious mergers and acquisitions, companies should develop effective defensive provisions according to their own circumstances.

The dispute over ownership and the nature of mergers and acquisitions is a battle over control, the appointment of management through the acquisition of boardroom seats. Based on this, on the one hand, the existing board of directors of an enterprise can clearly stipulate the right to propose shareholders 'meeting in the articles of association, the number of shareholders to nominate directors, the shareholders' right to nominate directors and the members of the board of directors. These rules allow malicious acquirers to understand that even if they acquire a large amount of equity, they will not be able to exercise their right of control by re-selecting the board of directors in a relatively short period of time. On the other hand, enterprises should be cautious in the constitution of the company according to their own conditions in the case of compliance. Vanke set oversight on major issues, exacerbated the share crisis, the future business should take this as a warning, according to their own specific conditions and ownership structure of the Articles of Association to improve. By designing good and effective articles of association, we can establish a good defense mechanism and make up for possible loopholes in the ownership structure.

\section{References}

[1] .KhannaTarun, Krishna Palepu, "Is Group Affiliation Profitable in Emerging Markets? An Analysis of Diversified IndianBusiness Groups", Journal of Finance, 2000, 55 (2) : 867 891.

[2] Gillan, S. and L. T. Starks, "Corporate Governance Proposals and Shareholder Activism: The Role of Institutional Investors”, Journal of Financial Economics, 2008, 57. 
[3] Berle A. Mean G, The Modern Corporation and Private Property [M], New York: Macmillan,1932:12.

[4] Pagano, Marco, Alisa Roell," The choice of stock ownership structure: agency costs, monitoring, and the decision to go Public", Quarterly Journal of Economies, 1998, 113: 187-226.

[5] Henrik Cronqvist and Mattias Nilsson, "Agency Costs of Controlling Minority Shareholders", SSE/EFI Working paper Series in Economics and Finance, 2001, No.364.

[6] Claessens S. , "Corporate Governance and Equity Prices: Evidence from the Czech and Slovak Republics", Journal of Finance, 1997, (52) :1641-1679.

[7] Pedersen H and Thomsen S. , "The Financial and Operating Performance of Europe Corporate", Journal of Finance, 1999, 52. 